ENTREPRENEURSHIP AND SUSTAINABILITY ISSUES

ISSN 2345-0282 (online) http://jssidoi.org/jesi/

2019 Volume 6 Number 3 (March)

http://doi.org/10.9770/jesi.2019.6.3(2)

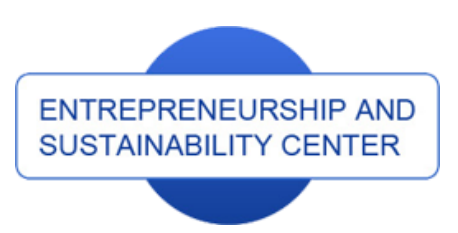

Publisher

http://jssidoi.org/esc/home

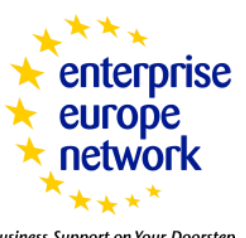

Business Support on Your Doorstep

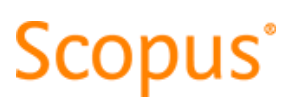

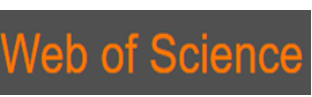

1) Clarivate

Analytics

\title{
MODEL OF SUSTAINABLE REGIONAL DEVELOPMENT WITH IMPLEMENTATION OF BROWNFIELD AREAS
}

\author{
Henrieta Pavolová1, Tomáš Bakalár ${ }^{2}$, Elsanosi Mohamed Abdelhafiez Emhemed ${ }^{3}$, \\ Zuzana Hajduová ${ }^{4}$, Martin Paf̌co 5
}

\author{
${ }^{1,2,3}$ Institute of Earth rescues, Technical University in Košice \\ ${ }^{4}$ Faculty of Business Economics with seat in Košice, University of Economics in Bratislava, Slovakia \\ ${ }^{5}$ Faculty of Economics and Business, Pan-European University in Bratislav, Slovakia
}

E-mails: ${ }^{1}$ henrieta.pavolova@tuke.sk; $\frac{2 \text { tomas.bakalar@tuke.sk }}{\underline{5} \text { martinpafco@hotmail.com }}{ }^{3 \text { allhur1@hotmail.com }}{ }^{4} \underline{\text { zuzana.hajduova@euke.sk, }}$

Received 15 August 2018; accepted 20 January 2019; published 30 March 2019

\begin{abstract}
The article highlights the potential of brownfield areas in the sense of the rules and principles of sustainable development of the regions which shows significant disparities determined by the developmental tendencies of the socio-economic and environmental spheres, whose interactions were its basic platform in the Slovak Republic in the last years. Brownfield areas, with a degree of degradation and environmental quality depending on their type and original use, have a negative impact on all mentioned spheres of regional development, since such sites are unused and represent so-called brown investments, i.e. areas from which the region has no benefit. From the explicitly defined positive and negative determinants of the actual occurrence of brownfield areas in terms of sustainable development of the regions, the article quantifies their prioritization in the process of implementation into the regional development model, accepting the principles of Saaty matrix which is objective from a process perspective of sustainable regional development. Based on the explicit quantification of the above-mentioned determinants, the categorization of brownfield areas in the process of sustainable regional development, including the model of regional development with implemented brownfield sites, whose actual occurrence supports the occurrence of diversified activities, reduces the price of the surrounding land and ultimately threatens the health of the affected population and reduces the price of surrounding lands.
\end{abstract}

Keywords: brownfield areas; sustainable development; model of regional development; Saatys matrix

Reference to this paper should be made as follows: Pavolová, H.; Bakalár, T.; Emhemed, E.M.A, Hajduová, Z.; Pafčo, M. 2019. Model of sustainable regional development with implementation of brownfield areas, Entrepreneurship and Sustainability Issues 6(3): 1088-1100. $\underline{\text { http://doi.org/10.9770/jesi.2019.6.3(2) }}$

JEL Classifications: L16, O14, O44

Additional disciplines ecology and environment; engineering 


\section{ENTREPRENEURSHIP AND SUSTAINABILITY ISSUES}

ISSN 2345-0282 (online) http://jssidoi.org/jesi/

2019 Volume 6 Number 3 (March)

http://doi.org/10.9770/jesi.2019.6.3(2)

\section{Introduction}

Sustainable development can be defined as the environment as "a development that preserves the opportunity to satisfy their basic living needs to the present and future generations while not diminishing the diversity of nature and preserving the natural functions of ecosystems" within the meaning of $\S 6$ of Act no. 17/1992 Coll. on the Environment. Based on the fact that brownfield sites are an integral part of the environment of individual regions whose presence is negative (Pavolová et al., 2012, Khouri et al., 2016) it is necessary to eliminate their real occurrence and focus on sustainable development towards brownfield sites themselves in interaction with their reuse (Pavolová et al. 2012; Brzeszczak \& Imiołczyk, 2016; Dobrovolskiené et al. 2017). In the view of the above mentioned, sustainable regional development with an implemented system use of brownfield sites can be characterized as a strategic, complex and synergic process determining the socio-economic, environmental and institutional aspects of regional development, profiling a functional model of anthropogenic society eliminating the interventions that threaten, damage or devastate the living conditions, adequate use of natural resources and protection of cultural and natural heritage (MoE SR, 20\%; Melichova et al., 2017). In the reality of growing international competition, entrepreneurship is crucial for building effective economy both at national and regional level (Ignatavičius et al., 2015; Agrawal, 2016; Pietrzak \& Balcerzak, 2016; Cseh Papp, 2018; Tvaronavičienė, 2016; Saeed et al. 2017; Meyer et al., 2016; Yan et al., 2017; Brzeszczak \& Imiołczyk, 2016; Melas et al., 2017; Ponomarenko et al., 2018; Razminienė \&Tvaronavičienė, 2018).

\section{General characteristics of brownfield areas from the point of their implementation in the sphere of regional development}

Brownfields were created as a result of restructuring of the states and their individual regions. They are one of the consequences of radical changes in the socio-economic structure characterized by the shift of labor from primary (agriculture, forestry) to secondary (industry and construction) and nowadays into tertiary (trade, transport, services, public administration) spheres of civil life. Brownfield areas are a turbulent problem and an obstacle to further sustainable development in the regions as they are characterized by obscure property rights and layout, devastated production and non-production buildings and, in many cases, by the presence of old environmental burdens. These are represented by various substances, often toxic, that contaminate all the components of the environment (soil, surface and ground water, air, biota) as well as by material objects. On the particular land and in the particular buildings waste, including hazardous waste from the previous use of the land and buildings is often collected or temporarily stored. Significant risk is the remnants of machinery and technology that may contain chemicals that are hazardous to the environment and human health (PCBs, dioxins, etc.). Surroundings of brownfield areas are clearly visible and especially dangerous (Pavolová et al., 2012). The degree of degradation of brownfield areas and the level of environmental quality depend directly on their type and original use, which also determines the financial means associated with their revitalization in favour of sustainable regional development. This fact is also complicated by different understanding of brownfield areas in selected countries of the European Union (Table 1), which also complicates their implementation in a unified definition of sustainable development (Pavolová \& Kysel'ová, 2011; Beck, 2016; Tvaronavičiené \& Razminiene, 2017; Mura et al. 2017). Their elimination would not only contribute to the improvement of the environmental quality but also to further socioeconomic development of the regions where the brownfield area is located, including the primary, secondary and tertiary sphere of small and medium-sized enterprises in the SR which is in direct interaction with the sustainable regional development. The implementation of brownfield areas in the sustainable development of regions also directly depends on their generally defined positive aspects in a particular region as shown in Table 2 (Pavolová et al., 2012). 
ENTREPRENEURSHIP AND SUSTAINABILITY ISSUES

ISSN 2345-0282 (online) http://jssidoi.org/jesi/

2019 Volume 6 Number 3 (March)

http://doi.org/10.9770/jesi.2019.6.3(2)

Table 1. An overview of brownfield definitions in selected countries

\begin{tabular}{|l|l|}
\hline Country & Definition of brownfields areas \\
\hline Bulgaria & $\begin{array}{l}\text { Contaminated land - areas in which previous activity has ceased,however, still have influence on their } \\
\text { surroundings }\end{array}$ \\
\hline Belgium - Wallonia & $\begin{array}{l}\text { Places formerly intended for economic recovery, where the status quo is not an efficient use of } \\
\text { Flanders: An abandoned or underutilized industrial area with potential for active recovery or expansion, } \\
\text { which is further complicated by the development of real or anticipated environmental problems }\end{array}$ \\
\hline Czech republic & $\begin{array}{l}\text { Brownfield is a property (land, building, complex), which is underused, neglected and may be } \\
\text { contaminated. There is a remnant of the industrial, agricultural, residential, military or other activities. } \\
\text { Brownfield is not used appropriately and effectively without the normal process of regeneration. }\end{array}$ \\
\hline Denmark & Contaminated areas. \\
\hline France & $\begin{array}{l}\text { Previously, land use, are now temporarily or permanently abandoned due to attenuation of activity and } \\
\text { need to find a possible future use. They can be partially built, derelict or contaminated. }\end{array}$ \\
\hline Finland & No definitions. \\
\hline Ireland & $\begin{array}{l}\text { The abandoned areas - areas that have lost or losing their original character and negatively affect their } \\
\text { environment due to their dilapidated, disrepair, or the presence of waste }\end{array}$ \\
\hline Italy & $\begin{array}{l}\text { Contaminated areas - areas that are chemically, physically or biologically contaminated in such a way } \\
\text { that endangers human health or the surrounding buildings or landscape. The area is considered } \\
\text { contaminated when contamination exceeds the limits set by law. }\end{array}$ \\
\hline Hungary & $\begin{array}{l}\text { The territory which had formerly been used economically efficient, but are currently underused, } \\
\text { stopped. The main feature is the neglect, dereliction and contamination }\end{array}$ \\
\hline Cancelled due to contaminated areas - high density of landfills \\
\hline Poland & Impaired / deserted area usually built within urban areas \\
\hline Spain - Basque & Potentially contaminated areas / derelict industrial buildings \\
\hline Slovakia & $\begin{array}{l}\text { Brownfield is a property that is not effectively used, is neglected and possibly contaminated. This is a } \\
\text { property that can not be effectively used without a process of its regeneration. }\end{array}$ \\
\hline
\end{tabular}

Source: Pavolová, Kysel’ová, 2011

Table 2 Positive aspects of the removel of brownfileds areas in

\begin{tabular}{|l|c|}
\hline Removal of threats & $\begin{array}{c}\text { elimination of health hazards (toxins, carcinogenic, teratogenic, mutagenic, } \\
\text { other contaminants), physical hazards (unstable structures, wells, risks of } \\
\text { floods and flooding, burning dumps, etc.). }\end{array}$ \\
\hline $\begin{array}{l}\text { Removal of costs incurred in the destination area } \\
\text { to no } \\
\text { avail }\end{array}$ & $\begin{array}{c}\text { elimination of the cost of the brownfields area without benefit to ensure the } \\
\text { safety, infrastructure and other social costs }\end{array}$ \\
\hline $\begin{array}{l}\text { The acquisition of new land and development } \\
\text { opportunities of destination }\end{array}$ & $\begin{array}{c}\text { importance in regional destinations with a small development area, } \\
\text { minimizing the occupancy of new plots and the possibility of using them } \\
\text { preserving the natural environment for the benefit of regional development }\end{array}$ \\
\hline Increasing the attractiveness of regions & $\begin{array}{c}\text { improving the image, quality of the environment, life, positive aspect of } \\
\text { value and further development of the region in all areas of sustainable } \\
\text { development }\end{array}$ \\
\hline
\end{tabular}

Source: Authors

For all of the above reasons, cities and communities have to be aware of "their brownfield sites," make them aware in the preparation of territorial documentation and engage in both formal and informal support for their revitalization and re-use to help private sector investments which are necessary in their revitalization in promoting the sustainable development of the regions. For the needs of of brownfield sites implementation in the sustainable development of the regions it is necessary to prioritize their negative and positive determinants which, in their synergic effect, will point to their categorization and position in the process of reducing the interregional disparities which show significant differences with a pronounced polarization in Bratislava region, which is also documented by Fig. 1 on the occurrence of brownfield sites in the SR in recent years. According to the available data and the occurrence of brownfields in the SR it can be stated that the largest area of brownfields is located in the regions of eastern Slovakia, up to $35.97 \%$, i.e. 641.4 ha of the total area, but this is not true about their number 
because the most brownfield areas are located in the regions of Central Slovakia up to $42.08 \%$, i.e. 287 of the total number of brownfields occurring in the Slovak Republic according to this criterion. (Fig. 1).

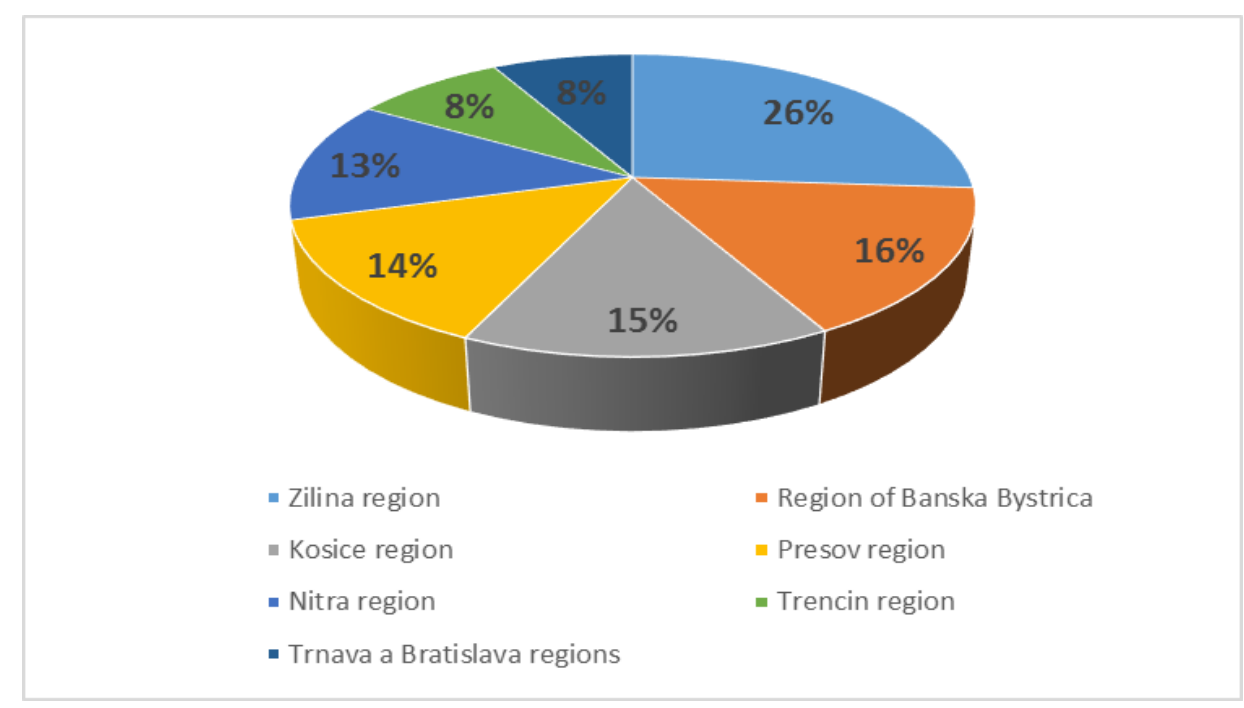

Fig.1. Brownfields in the Slovak Republic Source: SARIO

\section{Methodology of determinants quantification for the implementation of brownfield areas in the process of sustainable development of regions}

Analytic Hierarchy Process (AHP) is a multi-criteria decision making method, originally developed by mathematician Thomas L. Saaty, and is a tool with numerous applications in areas of planning and management (Saaty T. L., 1980). It can be used for evaluations of different problems in urban landscape management (Li, 2005; Simo et al. 2016; Srdjevic, Lakicevic, \& Srdjevic, 2013; Grancay et al, 2015; Svec \& Madlenak, 2017; Dolobac et al., 2015; Kim \& Sato, 2000; Adamisin et al. 2018). AHP uses a pairwise comparison method to generate weightings (ratio scales) for criteria, instead of simply listing and ranking the levels of importance. There are some methods (Benda-Prokeinová et al., 2017). Saaty's method of weighting the criteria is done in two steps. First we determine the matrix of the intensity of preferences S. The elements of the S-matrix, which we call sij (ith line, $\mathrm{j}$-th column), are obtained by examining the number of times the criterion $\mathrm{Ki}$ is more significant than the criterion $\mathrm{Kj}$, if it is more significant or as significant as . This ratio of the significance of two criteria, which is expressed by elements sij, can also be interpreted as the ratio of their weights:

$$
s_{i j}=\frac{v_{i}}{v_{j}}, \quad \mathrm{i}, \mathrm{j}=1,2, \ldots, \mathrm{m}
$$

Based on the number of times the criterion is more significant than, we assign the elements of the intensity preference matrix $S$ numbers from 1 to 9. (Ramík J., 2000). If it is $K_{j}$ more important then $K_{i}$, we will define the elements $s_{\mathrm{ij}}$ as follows: 


$$
s_{i j}=\frac{1}{s_{j i}}
$$

This relationship can be described as follows: If the criterion $K_{i}$ is $s_{i j}$ - times more significant than the criterion $\mathrm{K}_{\mathrm{j}}$. If for all elements of the matrix $\mathrm{S}$ the relation (2) holds, then we say that the matrix $\mathrm{S}$ is reciprocal. The second step is to determine the scales themselves based on the knowledge of the $\mathrm{S}$ matrix, which minimizes the expression (Talašová, J., 2003):

$$
D=\sum_{i=1}^{m} \sum_{j=1}^{m}\left(s_{i j}-\frac{v_{i}}{v_{j}}\right)^{2}
$$

under the condition

$$
\sum_{i=1}^{m} v_{i}=1
$$

For the purpose of defining the prioritization of determinants of brownfield areas implementation in the sustainable development process of regions a tabulated overview was created in two areas - positive and negative determinants. All the determinants were added a numerical value of the weight by accepting the generally valid condition.This symmetrical matrix also corresponds to the fact that the method is based on the interactive comparison of all predefined determinants of the same rank with the evaluation in Table 3 (Hlavňová, Pavolová, 2017).

Table 3. Assessment of negative and positive determinants in Saaty matrix

\begin{tabular}{|c|c|}
\hline Determinant Value & Description of Comparative Determinants \\
\hline 1 & Determinants $\mathrm{i}$ and $\mathrm{j}$ are equivalent \\
\hline 3 & The determinant $\mathrm{i}$ is slightly preferred over the determinant $\mathrm{j}$ \\
\hline 5 & The determinant $\mathrm{i}$ is strongly preferred over the determinant $\mathrm{j}$ \\
\hline 7 & The determinant $\mathrm{i}$ is very strongly preferred over the determinant $\mathrm{j}$ \\
\hline 9 & The determinant $\mathrm{i}$ is absolutely preferred over the determinant $\mathrm{j}$ \\
\hline
\end{tabular}

Source: Hlavňová, Pavolová, 2017

Consequently, the values of 1 were assumed on the diagonal of the matrix, as we accepted the principle of comparison of the same factors, i.e. their equivalence, and identified pairwise comparisons of the individual factors. If the factor in the row is preferred over the factor in the column, the reciprocal value was attributed. Furthermore, the $\mathrm{R}_{\mathrm{i}}$ values for each criterion were quantified, i.e. row of matrix created according to the formula:

$$
\begin{aligned}
\mathrm{R}_{\mathrm{i}}=\left(S_{i}\right)^{\frac{1}{f}} & \\
& \mathrm{f}-\text { number of factors, } \\
& \mathrm{S}_{\mathrm{ij}}-\text { particular factors. }
\end{aligned}
$$




\section{ENTREPRENEURSHIP AND SUSTAINABILITY ISSUES}

ISSN 2345-0282 (online) http://jssidoi.org/jesi/

2019 Volume 6 Number 3 (March)

http://doi.org/10.9770/jesi.2019.6.3(2)

Based on these calculations, the sum of $\mathrm{R}_{\mathrm{i}}$ was calculated and based on it the final value of individual weights reflecting the interactions of the different determinants and their prioritization in the process of sustainable development of the regions was calculated.

\section{Sustainable development model of regions with implementation of brownfield areas}

In terms of the definition of sustainable development and the above-mentioned facts about brownfields it was possible to define their negative and positive determinants for their implementation into a systemic approach supporting the sustainable development of the regions. The negative determinant of the occurrence of brownfield sites in regions that hinder their sustainable development include: the decline in the economic performance of the region (D1), the greenfield competition (D2), the reduction of the aesthetic nature of the landscape (D3), the threat to the health of the population (D4), insufficient return on investments in brownfield sites regeneration (D5), the possibility of environmental burdens and associated additional investment to remediate them (D6), the occurrence of devastated buildings (D7), the non-use of brownfield sites in the development of the region (D8) and the reduction of the territorial ecological stability system (D9) and their weight values for the need to define their prioritization in the process of sustainable development of the regions were quantified (Table 4). Among the positive determinants of the use of brownfield sites in the systematic process of supporting the sustainable development of the regions were included: sustainable use of the area in the region (D1), support for social development (D2), increasing employment in the region (D3), promotion of economic development due to regeneration of brownfield sites and their re-use (D4), enhancing environmental quality by removing environmental burdens, (D6), increasing the purchasing power of the population (D6), and increasing the average wage in the region (D7) due to the re-use of brownfield sites by supporting small and medium-sized enterprises in the region (D8), increasing the competitiveness of the region (D10) and the improvement of population life quality (D11) and, by the same procedure, the values of their weights and the need to define their priority in the process of sustainable development of the regions were quantified (Table 5).

Table 4. Quantification of negative determinants of brownfield sites

\begin{tabular}{|c|c|c|c|c|c|c|c|c|c|c|c|c|}
\hline Determinant & D1 & D2 & D3 & D4 & D5 & D6 & D7 & D8 & D9 & $\mathbf{S}_{\mathbf{i}}$ & $\mathbf{R}_{\mathbf{i}}$ & $\mathbf{v i}_{\mathbf{i}}$ \\
\hline D1 & 1 & 5 & 5 & 3 & 3 & 3 & 3 & 3 & 3 & 18225.0000 & 2.974 & 0.26 \\
\hline D2 & $1 / 5$ & 1 & 7 & $1 / 3$ & $1 / 3$ & 1 & 3 & 1 & $1 / 3$ & 0.1556 & 0.813 & 0.07 \\
\hline D3 & $1 / 5$ & $1 / 7$ & 1 & $1 / 5$ & $1 / 7$ & $1 / 5$ & $1 / 7$ & 3 & $1 / 3$ & 0.0000 & 0.306 & 0.03 \\
\hline D4 & $1 / 3$ & 3 & 5 & 1 & 5 & 3 & 5 & 7 & 1 & 2625.0000 & 2.398 & 0.21 \\
\hline D5 & $1 / 3$ & 3 & 7 & $1 / 5$ & 1 & $1 / 3$ & 1 & 1 & $1 / 5$ & 0.0933 & 0.768 & 0.07 \\
\hline D6 & $1 / 3$ & 1 & 5 & $1 / 3$ & 3 & 1 & 3 & 3 & 1 & 15.0000 & 1.351 & 0.12 \\
\hline D7 & $1 / 3$ & $1 / 3$ & 7 & $1 / 5$ & 1 & $1 / 3$ & 1 & 1 & $1 / 5$ & 0.0104 & 0.602 & 0.05 \\
\hline D8 & $1 / 3$ & 1 & $1 / 3$ & $1 / 7$ & 1 & $1 / 3$ & 1 & 1 & $1 / 3$ & 0.0018 & 0.494 & 0.04 \\
\hline D9 & $1 / 3$ & 3 & 3 & 1 & 5 & 1 & 5 & 3 & 1 & 225.0000 & 1.825 & 0.16 \\
\hline Sum & & & & & & & & & & & 11.533 & 1.00 \\
\hline
\end{tabular}

Source: Authors 
ENTREPRENEURSHIP AND SUSTAINABILITY ISSUES

ISSN 2345-0282 (online) http://jssidoi.org/jesi/

2019 Volume 6 Number 3 (March)

http://doi.org/10.9770/jesi.2019.6.3(2)

Table 5. Quantification of positive determinants of brownfield sites

\begin{tabular}{|c|c|c|c|c|c|c|c|c|c|c|c|c|c|c|}
\hline Determinant & D1 & D2 & D3 & D4 & D5 & D6 & D7 & D8 & D9 & D10 & D11 & $\mathbf{S}_{\mathbf{i}}$ & $\mathbf{R}_{\mathbf{i}}$ & $\mathbf{v}_{\mathbf{i}}$ \\
\hline D1 & 1 & 3 & $1 / 3$ & $1 / 3$ & $1 / 9$ & $1 / 5$ & $1 / 5$ & $1 / 7$ & $1 / 7$ & $1 / 5$ & $1 / 5$ & 0.000001 & 0.290 & 0.02 \\
\hline D2 & $1 / 3$ & 1 & 1 & 1 & $1 / 3$ & $1 / 3$ & $1 / 3$ & $1 / 3$ & 1 & 1 & $1 / 3$ & 0.001372 & 0.549 & 0.04 \\
\hline D3 & 3 & 1 & 1 & 3 & 1 & $1 / 3$ & 1 & $1 / 3$ & $1 / 3$ & 1 & 1 & 0.333333 & 0.905 & 0.07 \\
\hline D4 & 3 & 1 & $1 / 3$ & 1 & 3 & 3 & 1 & 3 & $1 / 3$ & $1 / 3$ & 1 & 3.000000 & 1.105 & 0.09 \\
\hline D5 & 9 & 3 & 1 & $1 / 3$ & 1 & $1 / 3$ & $1 / 3$ & $1 / 3$ & $1 / 3$ & $1 / 5$ & $1 / 3$ & 0.007407 & 0.640 & 0.05 \\
\hline D6 & 5 & 3 & 3 & $1 / 3$ & 3 & 1 & 1 & 3 & $1 / 3$ & $1 / 3$ & $1 / 3$ & 5.000000 & 1.158 & 0.09 \\
\hline D7 & 5 & 3 & 1 & 1 & 3 & 1 & 1 & 5 & $1 / 3$ & $1 / 3$ & $1 / 3$ & 8.333333 & 1.213 & 0.09 \\
\hline D8 & 7 & 3 & 3 & $1 / 3$ & 3 & $1 / 3$ & $1 / 5$ & 1 & $1 / 3$ & $1 / 5$ & $1 / 3$ & 0.093333 & 0.806 & 0.06 \\
\hline D9 & 7 & 1 & 3 & 3 & 3 & 3 & 3 & 3 & 1 & 3 & $1 / 3$ & 5103.000000 & 2.173 & 0.17 \\
\hline D10 & 5 & 1 & 1 & 3 & 5 & 3 & 3 & 5 & $1 / 3$ & 1 & 3 & 3375.000000 & 2.093 & 0.16 \\
\hline D11 & 5 & 3 & 1 & 1 & 3 & 3 & 3 & 3 & 3 & $1 / 3$ & 1 & 1215.000000 & 1.907 & 0.15 \\
\hline \multicolumn{13}{|l|}{ Sum } & 12.839 & 1.00 \\
\hline
\end{tabular}

Source: Authors

In terms of the quantified prioritization of negative and positive determinants it was found that the highest priority in preventing the use of brownfield sites, i.e. the negative determinants represented were the decline in the economic performance of the region $(25.79 \%)$ and the reduction of the territorial system of ecological stability $(15.83 \%)$ and the lowest priority were reduction of the aesthetic character of the landscape area $(2.65 \%)$ and the non-use of brownfield sites $(4.29 \%)$, while the highest priority of the use of these sites in the sustainable development processes among the positive determinants were increasing the competitiveness of the region (16.93\%), increasing the tax revenues of municipalities in the regions (16.30\%) and, on the other hand, the lowest priority were sustainable use of the regions in the region (2.26\%), social development support (4.28\%) (Fig. 2).
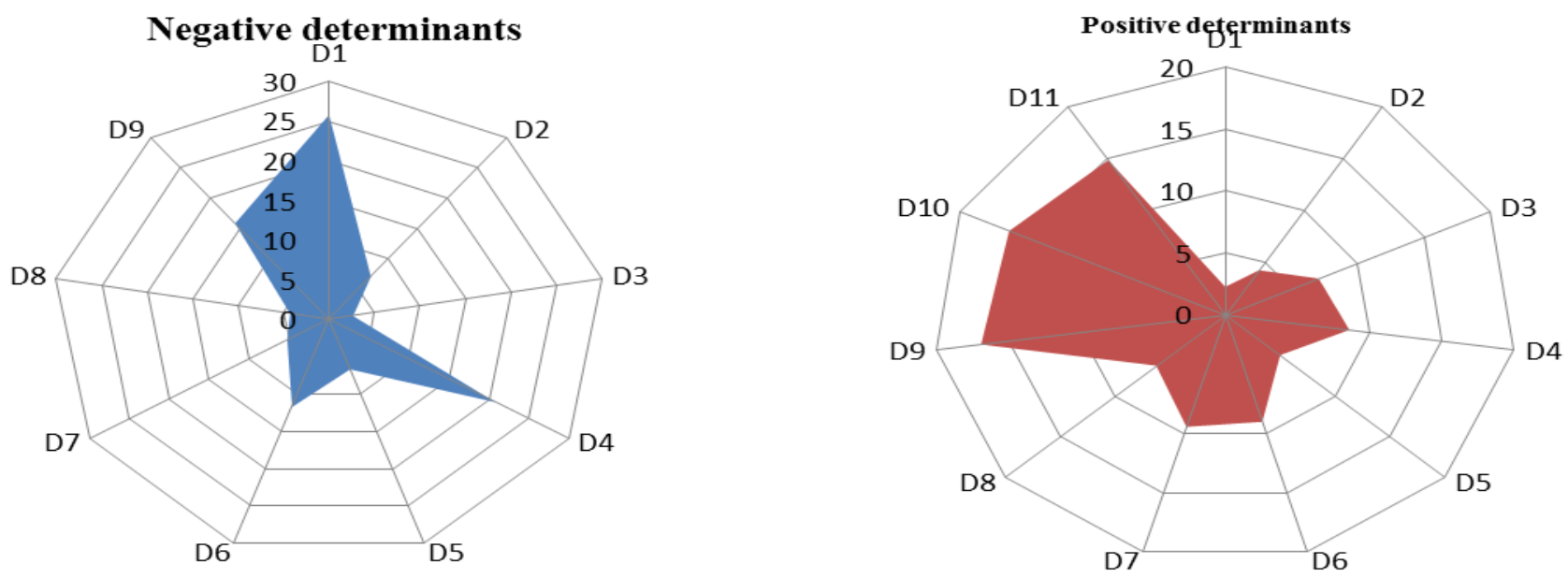

Fig.2. Prioritization of negative and positive determinants of brownfield areas in the process of sustainable development of regions Source: Authors 
ENTREPRENEURSHIP AND SUSTAINABILITY ISSUES

ISSN 2345-0282 (online) http://jssidoi.org/jesi/

2019 Volume 6 Number 3 (March)

http://doi.org/10.9770/jesi.2019.6.3(2)

The partial results of the prioritization of previously clearly defined single negative and positive determinants of the use of brownfield sites in the processes of sustainable development of the regions are consequently synthesized into a summary matrix of complex evaluation, which determines their implementation in the above mentioned processes in the form of a summary indicator - "Scoring Ratio" that could predict a specific category of regional development support in interacton with the ultimate benefit of investing in the regeneration and reuse of brownfield areas. Following the below-mentioned summary matrix of a comprehensive brownfield land use assessment in regional sustainable development processes (Table 6), it was found that the positive determinants of brownfield sites implementation in the sustainable development processes of the regions showed a prevalence $(52.68 \%)$ above the negative determinants of their occurrence $(47.32 \%)$, which hinders the development of the regions with a sum of 1.11 (Table 6), whereby it can also be predicted the category of regional development support and therefore the suitability of implementing brownfield sites in the sustainable development processes of the regions identified as IV. category, i.e. high support for the sustainable development of the regions, as the score ratio reached 1.71 (Table 7).

Table 6. A summary matrix of a comprehensive assessment of the use of brownfields in the processes of sustainable development of the regions

\begin{tabular}{|c|c|c|c|c|}
\hline Determinants & & $\begin{array}{l}\text { Determinants } \\
\text { Score }\end{array}$ & $\begin{array}{l}\text { Partial } \\
\text { Score }\end{array}$ & Scoring \\
\hline the economic performance of the region & - & 12.20 & \multirow{9}{*}{47.32} & \multirow{21}{*}{1.11} \\
\hline competition of greenfields & - & 3.34 & & \\
\hline reducing aesthetic landscape & - & 1.25 & & \\
\hline threats to population & - & 9.84 & & \\
\hline low return on regeneration of brownfield sites & - & 3.15 & & \\
\hline environmental burdens & - & 5.54 & & \\
\hline devastated buildings & - & 2.47 & & \\
\hline non-used territory & - & 2.03 & & \\
\hline reducing the territorial system of ecological stability & - & 7.49 & & \\
\hline sustainable use of land in the region & + & 1.19 & \multirow{12}{*}{52.68} & \\
\hline promoting social development & + & 2.25 & & \\
\hline increasing employment & + & 3.71 & & \\
\hline promoting economic development & + & 4.53 & & \\
\hline increasing environmental quality & + & 2.63 & & \\
\hline increasing purchasing power & + & 4.75 & & \\
\hline increasing the average wage in the region & + & 4.98 & & \\
\hline support for small and medium-sized businesses & + & 3.31 & & \\
\hline increasing the competitiveness of the region & + & 8.92 & & \\
\hline tax revenue growth of the municipality & + & 8.59 & & \\
\hline \multirow[t]{2}{*}{ increasing the quality of life of the population } & & & & \\
\hline & + & 7.83 & & \\
\hline
\end{tabular}

Source: Authors

Table 7. Categories of brownfield sites in processes of sustainable development of regions 
ENTREPRENEURSHIP AND SUSTAINABILITY ISSUES

ISSN 2345-0282 (online) http://jssidoi.org/jesi/

2019 Volume 6 Number 3 (March)

http://doi.org/10.9770/jesi.2019.6.3(2)

\begin{tabular}{|l|c|c|}
\hline \multicolumn{2}{|c|}{ Category } & Scoring \\
\hline I. category & Very high & Above 1,2 \\
\hline II. category & High & $\mathbf{1 , 1 9 - 0 , 9}$ \\
\hline III. category & Average & $\mathbf{0 , 8 9}-\mathbf{0 , 7}$ \\
\hline IV. category & Low & $\mathbf{0 , 6 9}-\mathbf{0 , 5}$ \\
\hline V. category & Very low & $\mathbf{0 , 4 9}-\mathbf{0 , 3}$ \\
\hline VI. category & Ineffective & $\mathbf{0 , 2 9}$ and less \\
\hline
\end{tabular}

An effective system of sustainable regional development management with an integral part of the use of brownfield areas should respect all the specifics of the affected region as well as the specific brownfield areas that are determined by their previous uses, including inputs, transformation technologies and outputs. In the so-called system of sustainable development management of the regions, it should also be taken into account the degree of degradation of the productive or non-productive objects, the material composition of structures and other building segments that could affect the total amount of investment needed to restore the brownfield. According to some authors (Khouri et al., 2016; Cehlár et al., 2013; Kováčik, Mariš.2014; Horecký, 2018; Lorincová, 2018), other factors that could directly influence the use of brownfields in the process of development of the regions include their location (urban or rural area), availability of funds (bank loans, EU funds), various forms of support programs by the state and public sector (both monetary and non-monetary). A brownfield management system, defined in such a way, in regional development processes should be characterized by clearly defined rules of monitoring and regular evaluation of predetermined development indicators, accepting principles of sustainable development at the level of the regions, and, of course, adhering to the legislative regulations related to the brownfield regeneration process.

A high level of cooperation and communication has a positive effect on innovation activity (Arndt \& Sternberg, 2000; Freel, 2003). In a number of cases, the emergence of cooperative relations is forced.The model of efficient management of the use of brownfield areas in the processes of sustainable development of the regions was designed to respect all external and internal factors affecting the sub-processes of regional development based on the regeneration and subsequent use of brownfields determining the final benefit derived from the comparative synthesis of the results of the evaluation of positive and negative determinants using the integrated scoring ratio as illustrated in the scheme of the brownfield management model in regional development in Fig. 3. 


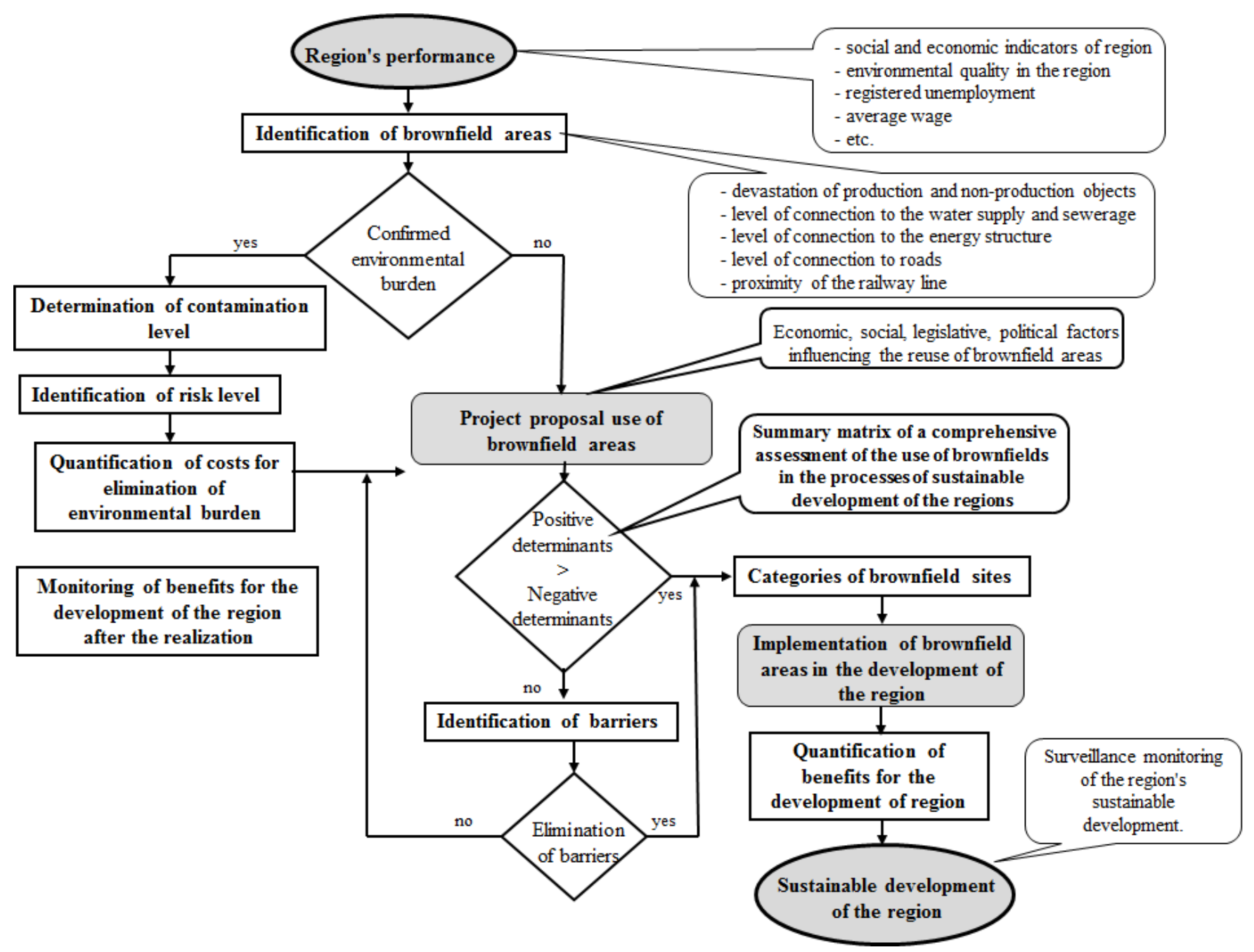

Fig. 3. Model of brownfields management in regional development

Source: Authors

\section{Conclusions}

The development in addressing brownfield issues with complicated recovery caused by unclear property rights, lack of information on the kind and extent of contamination determining the economic risks associated with recovery and the resulting additional liabilities. They point to the fact that these areas are not only an isolated problem in the regional development but also a problem whose solving by this strategy could be a reasonable profit to the sustainable development of the regions. The proposed model of the brownfield management system, in terms of sustainable development of the regions with the aim of reducing interregional disparities and increasing the competitiveness of Slovak regions was designed to integrate the following sub-areas of the solution of the analysed problem:

- the current state of brownfield areas, including the identification of its type according to its previous use or predominant use, 


\section{ENTREPRENEURSHIP AND SUSTAINABILITY ISSUES}

ISSN 2345-0282 (online) http://jssidoi.org/jesi/

2019 Volume 6 Number 3 (March)

http://doi.org/10.9770/jesi.2019.6.3(2)

- identify the environmental burden and quantify the financial costs associated with its elimination,

- a proposal for the regeneration and subsequent use of brownfield sites according to the needs and specifics of the particular region concerned,

- identifying and evaluating benefits and barriers factors, the pre-defined support category of the region according to the scoring ratio,

- $\quad$ surveillance monitoring of the development indicators of the affected region by using the direction of its development activities to the brownfield potential.

\section{References}

Adamisin, P., Kotulic, R., Mura, L., Kravcakova Vozarova, I., Vavrek, R. (2018). Managerial approaches of environmental projects: An empirical study. Polish Journal of Management Studies 17(1): 27-38. https://doi.org/10.17512/pjms.2018.17.1.03

Agrawal, R. (2016). 'Enterprise Risk Management' Essential for Survival and Sustainable Development of Micro, Small and Medium Enterprises. International Review 1-2: 117-123.

Arndt, O., \& Sternberg, R. (2000). Do manufacturing firms profit from intra-regional innovation linkages? An empirical-based answer. European Planning Studies, 8(4): 465-485. https://doi.org/10.1080/713666423

Beck, K. (2016). Business cycle synchronization in European Union: regional perspective. Equilibrium. Quarterly Journal of Economics and Economic Policy, 11(4), 785-815. https://doi.org/10.12775/EQUIL.2016.036

Benda-Prokeinová, R., Dobeš, K., Mura, L., Buleca, J. (2017). Engel's Approach as a tool for estimating consumer behaviour. E \& $M$ Ekonomie a Management 20(2): 15 - 29

Brzeszczak, A., Imiołczyk, J. 2016. Ratio analysis of Poland's sustainable development compared to the countries of the European Union. Acta Oeconomica Universitatis Selye 5(2): 31-41

Cehlar, M., \& Senova, A. (2013). Financing options for revitalizing of brownfields in Slovakia. In: SGEM 2013: 13th International Multidisciplinary Scientific Geoconference: Ecology, economics, education and legislation: conference proceedings 2: 16-22 June, 2013, Albena: STEF92 Technology Ltd., 2013 P. 161-168. - ISBN 978-619-7105-05-6.

Cseh Papp, I., Varga, E., Schwarczová L., Hajós, L. (2018). Public work in an international and Hungarian context. Central European Journal of Labour Law and Personnel Management 1(1): 6 - 16

Dobrovolskienè, N.; Tvaronavičienè, M.; Tamošiūnienè, R. (2017). Tackling projects on sustainability: a Lithuanian case study. Entrepreneurship and Sustainability Issues 4(4): 477-488. https://doi.org/10.9770/jesi.2017.4.4(6)

Dolobac, M., Mura, L., Svec. (2015). Personnel management and the new system of dual education in Slovak Republic. Actual Problems of Economics 181 (7): 282-289

Frenken, K., Van Oort, F., \& Verburg, T. (2007). Related variety, unrelated variety and regional economic growth. Regional Studies 41(5): 685-697. https://doi.org/10.1080/00343400601120296

Grancay, M., Grancay, N., Drutarovska, J., Mura, L. 2015. Gravity model of trade of the Czech and Slovak Republics 1995-2012: How have determinants of trade changed. Politicka Ekonomie 63(6): 759-777.

Horecký, J. (2018). Operation and action of a trade union (in terms of Czech Republic labour law). Central European Journal of Labour Law and Personnel Management, 1 (1), 17 - 27

Ignatavičius, R.; Tvaronavičienè, M.; Piccinetti, L. (2015). Sustainable development through technology transfer networks: case of Lithuania. Journal of Security and Sustainability Issues 4(3): 261-267. http://dx.doi.org/10.9770/jssi.2015.4.3(6)

Khouri, S., Pavolová, H. Cehlár, M. \& Bakalár, T. (2016). Metallurgical brownfields re-use in the conditions of Slovakia - a case study. Metalurgija. 2016, 55(3), 500-502 ISSN 0543-5846. 


\section{ENTREPRENEURSHIP AND SUSTAINABILITY ISSUES}

ISSN 2345-0282 (online) http://jssidoi.org/jesi/

2019 Volume 6 Number 3 (March)

http://doi.org/10.9770/jesi.2019.6.3(2)

Kim, K., \& Sato, S. (2000). Evaluation of Urban Landscape Problem Using Analytic Hierarchy Process Method. Computing in Civil and Building Engineering, 442-448.

Korcsmáros, E., Mura, L., Šimonová, M. (2017). Identification of small and medium-sized enterprises development in Slovakia. Journal of Applied Economic Sciences 12(6): 1702-1712

Kováčik, M., Mariš, M. (2014). Vertical unemployment of citizens in regional structure of Slovakia. Acta Oeconomica Universitatis Selye 3 (2): 78-87

Li, K.-1. (2005). Using analytic hierarchy process in urban road landscape evaluation. Journal of Wuhan University of Hydraulic and Electric Engineerin, 1.

Lietava, M., Fáziková, M. (2017). Selection of EU finaced projects and the territorial cohesion. Acta Oeconomica Universitatis Selye 6(1): $71-82$

Lorincová, S. (2018). Human resource and corporate culture: Gender-based differences in the assessment. Central European Journal of Labour Law and Personnel Management, 1 (1), pp. 28 - 45

Melas, V., Lisin, E., Tvaronavičienė, M., Peresadko, G., Radwański, R. (2017). Energy security and economic development: renewables and the integration of energy systems. Journal of Security and Sustainability Issues 7(1): 133-139. https://doi.org/10.9770/jssi.2017.7.1(11)

Melichová, K., Hrivnák, M., Roháčiková, O. (2017). Multiplier effects and economic impact of university spending - case study of sectoral and spatial aspects of expenditures of Slovak University of Agriculture in Nitra. Acta Oeconomica Universitatis Selye 6(2) : 119-137

Meyer, N., Meyer, D. F., Molefe, K. (2016). Barriers to Small Informal Business Development and Entrepreneurship: the Case of the Emfuleni Region. Polish Journal of Management Studies 13(1): 121-133. https://doi.org/10.17512/pjms.2016.13.1.12

Mura, L., Daňová, M., Vavrek, R., Dúbravská, M. (2017). Economic freedom - classification of its level and impact on the economic security. AD ALTA-Journal of Interdisciplinary Research 7(2): $154-157$

Pavolová, H., Csikósová, A. \& Bakalár, T. (2012). Brownfields as a tool for support of regional development of Slovakia. Applied Mechanics and Materials Vol. 209. Trans Tech Publications, 2012.

Pavolová, H., Seňová, A. \& Bakalár, T. (2012). Increase of Alternative and Renewable Energy Sources Utilization in Slovakia by 2020 in Comparison to other Selected EU Countries. Applied Mechanics and Materials Vol. 152. Trans Tech Publications, 2012.

Pavolová H., Kysel'ová, K. (2011). Resolving the issue of brownfields in conditions of the EU.

Pietrzak, M. B. \& Balcerzak, A. P. (2016). A Spatial SAR Model in Evaluating Influence of Entrepreneurship and Investments on Unemployment in Poland. In M. Reiff \& P. Gezik (Eds.). Proceedings of the International Scientific Conference Quantitative Methods in Economics Multiple Criteria Decision Making XVIII. Vratna: Letra Interactive, 303-308.

Ponomarenko, T., Khudolei, V., Prokopenko, O., Klisinski, J. (2018). Competitiveness of the information economy industry in Ukraine. Problems and Perspectives in Management 16 (1): 85-95

Ramík, J. (2000). Analytický hierarchický proces (AHP) a jeho využití v malém s středním podnikání [Analytical hierarchical process $(A H P)$ and its use in small and medium-sized business], Slezská univerzita v Opavě, Karviná.

Razminienè, K.; Tvaronavičienė, M. (2018). Detecting the linkages between clusters and circular economy. Terra Economicus 16(4): 50-65 http://dx.doi.org/10.23683/2073-6606-2018-16-4-50-65

Saaty, T. L. (1990). How to make a decision: the analytic hierarchy process. European journal of operational research 48(1): 9-26.

Saaty, T. L. (1980). The analytic hierarchy process: planning, priority setting, resource allocation, Mcgraw-Hill.

Saeed, J. M., Reza, Z. M., Hadi, S. (2017). Entrepreneurship Development Policymaking Factors: An exploratory survey of Tourism in Iran, International Review 1-2: 73-83.

Simo, D., Mura, L., Buleca, J. (2016). Assessment of milk production competitiveness of the Slovak Republic within the EU-27 countries. Agricultural Economics-Zemedelska Ekonomika 62(10) : 482-492. 
ENTREPRENEURSHIP AND SUSTAINABILITY ISSUES

ISSN 2345-0282 (online) http://jssidoi.org/jesi/

2019 Volume 6 Number 3 (March)

http://doi.org/10.9770/jesi.2019.6.3(2)

Srdjevic, Z., Lakicevic, M., \& Srdjevic, B. (2013). Approach of decision making based on the analytic hierarchy process for urban landscape management. Environmental management 51(3), 777-785.

Svec, M., Madlenak, A. (2017). Legal frameworks for the phygital concept. European Journal of Science and Theology 13 (6): $209-217$

Talašová, J. (2003). Fuzzy metody vícekriteriálního hodnocení a rozhodování [Fuzzy methods of multicriterial evaluation and decision making, VUP, Olomouc.

Tvaronavičienė, M. (2016). Entrepreneurship and energy consumption patterns: case of hoseholds in selected countries, Entrepreneurship and Sustainability Issues 4(1): 74-82. https://doi.org/10.9770/jesi.2016.4.1(7)

Tvaronavičienė, M., Razminiene, K. (2017). Towards competitive regional development through clusters: approaches to their performance evaluation. Journal of Competitiveness 9(4): 133-147. https://doi.org/10.7441/joc.2017.04.09

Yan T., Yay, G.G., Aksoy, T. (2017). Impact of institutions on entrepreneurship: a panel data analysis Euroasian Economic Review, Published online 9 September 2017 https://doi.org/10.1007/s40822-017-0082-0

Short biographical note about the contributors at the end of the article (name, surname, academic title and scientific degree, duties, research interests):

Henrieta PAVOLOVÁ is an associate professor. She is a lecturer, author, researcher and consultant, teacher at Technical University of Kosice, Faculty of Mining, Process Control and Geotechnology. Her publication activities involve articles, textbooks and monographs on such area.

ORCID ID: $\underline{\text { http://orcid.org/0000-0002-6507-0486 }}$

Tomáš BAKALÁR is an Assistant Professor at Technical University of Kosice, Faculty of Mining, Process Control and Geotechnology.

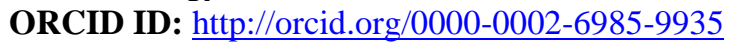

Elsanosi Mohamed Abdelhafiez EMHEMED is a PhD. student at Technical University of Kosice, Faculty of Mining, Process Control and Geotechnology.

ORCID ID: https://orcid.org/0000-0001-7408-8816

Zuzana HAJDUOVA is an expert on statistical methods, mass data processing, combinatorial structures and systems theory, as well as their application in economic practice. She concentrates her empirical research on quality, focusing on Six Sigma. She has a rich and thematically extensive publishing activity. She is a member of many scientific committees of international and national conferences. She participated in several domestic and international projects (Interreg IV.C, V4, Horizont 2020).

ORCID ID: $\underline{\text { https://orcid.org/0000-0002-9381-776X }}$

Martin PAFČO is a PhD. student at Pan-European University in Bratislava, Faculty of Economics and Business.

ORCID ID: https://orcid.org/0000-0003-3166-6799

Register for an ORCID ID:

https://orcid.org/register

Copyright (C) 2018 by author(s) and VsI Entrepreneurship and Sustainability Center

This work is licensed under the Creative Commons Attribution International License (CC BY).

http://creativecommons.org/licenses/by/4.0/

c) (i) Open Access 